\title{
IMPLEMENTASI NILAI-NILAI PERSATUAN \\ PADA PELAKSANAAN UPACARA HARI RAYA GALUNGAN \\ DALAM PERSPEKTIF BHINEKA TUNGGAL IKA \\ DI DESA BAGOREJO KECAMATAN SRONO
}

\author{
Yogi Ari Purnami ${ }^{1}$ Bayu Indra Permana ${ }^{2}$ \\ Universitas PGRI Banyuwangi \\ Program Studi Pendidikan Pancasila \& Kewarganegaraan \\ Yogiari.purnami@yahoo.com bayuindraper@gmail.com
}

\begin{abstract}
ABSTRAK
Bangsa Indonesia sangatlah heterogen dan pluralis, yang bermacam-macam agama, suku, ras, budaya, adat istiadat dan ideologi yang berbeda-beda dari masing-masing agama, atau budaya bahkan suku tersebut. Keberadaan masyarakat di Desa Bagorejo dalam sosial keagamaan terjalin dengan harmonis. Pelaksanaan Hari Raya Galungan adalah sebagai momentum bagi umat Hindu untuk menunjukan kebersamaan dalam pelaksanaan keagamaan. Kehidupan sehari-hari masyarakat di Desa Bagorejo hidup berdampingan sebagai wujud dari keharmonisan dalam beragama. Sosial relegius masyarakat di Desa Bagorejo, menunjukan eksistensi kebhinekaan yang sangat beradab.Penelitian ini bertujuan untuk mengetahui 1).Bagaimanakah konsep keberagamaan di Desa Bagorejo dalam pelaksanaan Hari Raya Galungan Perspektif Bhineka Tunggal Ika.2).Implementasi apa saja yang dilakukan umat Hindu di Desa Bagorejo Kecamatan Srono dalam mewujudkan sikap ke-Bhinekaan pada saat Hari Raya Galungan.3).Bagaimanakah perspektif Upacara Hari Raya Galungan di pandang dari Bhineka Tunggal Ika.

Jenis penelitian ini menggunakan metode kualitatif dengan pendekatan phenomologis dengan jumlah responden sebanyak 10 orang.Analisa data menggunakan deskriktif kualitatif.Hasil penelitian Implentasi yang terapkan umat Hindu dalam memujudkan sikap Bhineka Tunggal Ika adalah memahami dan melaksanakan konsep dan paham multikulturalisme dalam setiap perbedaanKonsep multikultur ini diterapkan dimasyarakat Desa Bagorejo, karena masyarakat Desa Bagorejo sangat pluralis dan heterogen. Kerukunan umat beragama di Desa Bagorejo menjadi contoh dan panutan bagi masyarakat luas. Kerukunan antar umat beragama di Desa Bagorejo dapat dilaksanakan dengan baik.
\end{abstract}

Kata kunci: implemenrtasi, persatuan

\section{PENDAHULUAN}

Keberadaan masyarakat di Desa Bagorejo dalam sosial keagamaan terjalin dengan harmonis. Pelaksanaan Hari Raya Galungan adalah sebagai momentum bagi umat Hindu untuk menunjukan kebersamaan dalam pelaksanaan keagamaan. Kehidupan sehari-hari masyarakat di Desa Bagorejo hidup berdampingan sebagai wujud dari keharmonisan dalam beragama. Sosial relegius masyarakat di Desa Bagorejo, menunjukan eksistensi kebhinekaan yang sangat beradab. Tim (2007:65) menyatakan bahwa dengan adanya kerukunan akan mempermudah dalam mencapai tujuan yang diinginkan. Demikian pula halnya dengan kehidupan beragama sudah tentu mengharapkan kerukunan disetiap langkah sehingga dalam menjalankan hidup dan kehidupan didunia ini dapat selaras, 
seimbang dan harmonis yang dilandasi oleh ajarannya masing-masing.

Adapun pelaksanaan hari Raya Galungan dan Kuningan yang dilaksanakan umat Hindu pada umumnya dan pada khususnya umat Hindu yang ada di Desa Bagorejo Kecamatan Srono, memegang teguh nilainilai kebhinekaan, fakta ini dicermati dari rangkaian pelaksanaan hari raya galungan, keberadaan masyarakat yang ada di Desa Bagorejo kerukunan kehidupan beragama sangat toleran untuk menciptakan hubungan yang harmonis antar umat beragama. Tradisi hari raya yang sangat kental dilaksanakan adalah tradisi anjangsana, yang sering dilakukan oleh masyarakat setempat. Banyaknya umat non-Hindu yang berkunjung dan bersilahturahmi kerumah umat Hindu, perilaku ini menandakan bahwa keberadaan masyarakat beragama di Desa Bagorejo sangat menjunjung tinggi nilai kebhinekaan

\section{METODE PENELITIAN}

Penelitian mengenai Implementasi Nilai-nilai Persatuan Pada Upacara Hari Raya Galungan di Desa Bagorejo merupakan penelitian kualitatif. Pendekatan tersebut digunakan untuk memperoleh informasi terkait dengan keberagaam antar umat beragama merupakan salah satu bentuk sosial sehingga masalah tersebut lebih tepat didekati dengan pendekatan kualitatif. Hal tersebut mengingat manusia sebagai mahluk individu sekaligus mahluk sosial memiliki sifat unik dan setiap tindakan dilakukan tidak saja karena faktor luar tetapi juga ada proses pemaknaan .Untuk mengetahui makna-makna dari suatu tindakan tidak dapat dilakukan dengan pendekatan kuantitatif, tetapi dapat ditangkap dengan pendekatan interpretatif-kualitatif

Kehadiran peneliti dalam penelitian kualitatif menggunakan instrumen penelitian, yaitu instrumen pokok dalam penelitian yang disebut dengan humanistrumen. Menurut Sugiyono (2010 : 305-306) menyatakan dalam penelitian kualitatif, yang menjadi instrumen atau alat penelitian adalah peneliti itu sendiri.

\section{Lokasi Penelitian}

Dalam penelitian ini, penentuan lokasi atau objek yang akan dijadikan untuk memperoleh data adalah di Desa Bagorejo Kecamatan Srono. Alasan penelitian yang dilakukan di Desa Bagorejo Kecamatan Srono. Dengan alasan bahwa lokasi yang ada di Desa Bagorejo Kecamatan Srono ini, merupakan salah satu lokasi yang tepat dalam meneliti tentang nilai-nilai keBhinekaan dalam keberagaman yang terjadi di Desa Bagorejo. Kehidupan keberagaman sangat nampak yang ditandai dengan kehidupan yang rukun saling menghargai dan sikap toleransi diciptakan setiap aktivitas dalam bersosialisasi.

Jenis data dalam penelitian ini disesuaikan dengan jenis penilitian. Jenis penelitian yang dilakukan adalah jenis penelitian kualitatif, karena penlitian yang dilakukan adalah penelitian lapangan, dimana dalam penelitian kualitatif bersifat natural setting sehingga dengan demikian jenis data yang digunakan adalah data kualitatif yaitu dengan katagori-katagori, gambar, informasi-informasi bukan dengan angka-angka. Jenis data dalam penelitian ini adalah data kualitatif yang berhubungan dengan kategorisasi, karakteristik, berwujud pertanyaan atau berupa kata-kata (Ridwan, 2004: 106).

Sumber Data dalam penelitian ini adalah subyek dari mana data dapat diperoleh. Apabila peneliti menggunakan wawancara, obeservasi, dokumentasi dan studi kepustakaan, dalam mengumpulkan datanya, maka sumber data disebut responden yaitu orang yang merespon atau menjawab pertanyaan-pertanyaan yang diajukan peneliti. Sumber data yang diperoleh dari penelitian ini berupa hasil penelitian terdahulu yang ada kaitannya 
dengan penelitian yang akan dilaksanakan maupun dari buku-buku yang berkaitan dengan ilmu pendidikan, sosial keagamaan dan kebudayaan yang ada kaitannya dengan rumusan masalah yang sedang dibahas. Adapun sumber data dalam penelitian ini adalah:

Menurut Iqbal, (2002: 82) menyatakan, data primer adalah data yang diperoleh dengan melakukan observasi atau dikumpulkan langsung di lapangan oleh peneliti atau yang bersangkutan yang memerlukannya.

Menurut Iqbal, (2002: 82) Data sekunder adalah data yang dikumpulkan oleh peneliti dari sumber-sumber yang telah ada. Data ini, biasanya diperoleh dari perpustakaan atau laporan penelitian terdahulu.Data sekunder disebut juga data tersedia. Selanjutnya Iqbal, (2002: 82) Data Sekunder adalah data yang dikumpulkan oleh peneliti dari sumber-sumber yang telah ada. Data ini, biasanya diperoleh dari perpustakaan, laporan penelitian terdahulu atau arsip-arsip dari suatu daerah yang di teliti.

Teknik pengumpulan data dalam penelitian akan digunakan tiga teknik yakni observasi partispasi, wawancara mendalam dan telaah dokumen. Teknik-teknik pengumpulan data tersebut menurut peneliti merupakan teknik pengumpulan data yang tepat dan mampu mengekplorasi atau menggali data yang diperlukan dalam penelitian ini.

Observasi partisipasi dalam penelitian ini merupakan teknik yang utama. Hal tersebut karena sesuai dengan jenis dan pendekatan penelitian yaitu interpretatifkualitatif. Observasi partisipasi atau observasi terlibat dalam penelitian ini peneliti akan ikut berpastisipasi dan mengamati secara langsung kegiatankegiatan pembinaan bagi umat Hindu di
Desa Bagorejo. Dalam observasi partisipasi peneliti sebagai instrumen akan berusaha menangkap segala sesuatu yang terkait dengan kehidupan Hindu. Dalam observasi partisipasi, peneliti juga akan mengamati secara mendalam mengenai kegiatankegiatan pembinaan, tindakan dan sikap yang terjadi dalam pembinaan.

Menurut Zuriah, (2007 : 179) wawancara adalah teknik pengumpulan data (informasi) dengan cara mengajukan sejumlah pertanyaan secara lisan untuk dijawab secara lisan pula. Ciri utama dari wawancara adalah adanya kontak langsung dengan tatap muka antara pencari informasi (interviewer) dan sumber informasi (interviewee). Arikunto, (2002 : 132), interviewer yang sering juga disebut dengan wawancara atau kuesioner lisan, adalah sebuah dialog yang dilakukan oleh pewawancara (interviewer) untuk memperoleh informasi dari terwawaancara (interviewer).

Dalam kaitannya dengan pokok permasalahan yang terdapat dalam penelitian ini, maka materi yang digunakan sebagai bahan inteview adalah hal-hal yang berkaitan dengan Nilai-nilai Persatuan Pada Pelaksanaan Hari Raya Galungan di Desa Bagorejo Kecamatan Srono Perspektif Bhineka Tunggal Ika.

Menurut Sayuti Ali, secara garis besar studi kepustakaan bersumber dari teori-teori dan konsep-konsep dari sumber bacaan umum seperti buku-buku teks, ensiklopledi, monografi, dan lain-lain. Generalisasi dapat ditarik dari sumber-sumber bacaan khusus seperi hasil-hasil penelitian terdahulu, jurnal, skripsi, tesis, disertasi, dan lain-lain. Prinsip yang harus dipegang adalah selektif, mutakhir dan relevan dengan masalah yang akan diteliti (Ali, 2003: 157). Teknik ini digunakan untuk membandingkan data yang diperoleh di lapangan dengan sumber- 
sumber lisan dan tertulis mengenai pendidikan agama Hindu luar sekolah baik dalam bentuk buku, buku yang digunakan adalah buku tentang pendidikan multikultur, buku-buku sosial keagamaan dan peraturan pemerintah, undang-undang pengajaran dan sebagainya.

Metode dokumentasi adalah metode pengumpulan data yang tidak langsung ditujukan pada subyek penelitian, namun melalui dokumentasi (Iqbal, 2002: 87). Berkaitan dengan penelitian ini, peneliti mengumpulkan data-data melalui photophoto yang diambil pada saat proses penelitian. Data-data doukumen atau catatan-catatan yang dapat menunjang dalam penelitian yang dilakukan. Adapun yang diphoto dalam penelitian ini adalah kegiatan-kegiatan yang dilakukan oleh pemangku terhadap kegiatan keagaman yang berhubungan dengan ajaran agama Hindu yang berlangsung di Desa Bagorejo Kecamatan Srono Kabupaten Banyuwangi

\section{HASIL DAN PEMBAHASAN}

\section{Konsep Keberagamaan Di Desa Bagorejo Dalam Pelaksanaan Hari Raya Galungan Perspektif Bhineka Tunggal Ika}

\section{Nilai Etika Hindu Dalam Menjaga Kebersamaan Antar Umat Beragama}

Setiap pelaksanaan etika atau susila keagamaan bagi seluruh umat beragama, disamping untuk menghubungkan diri kehadapan Tuhan Yang Maha Esa, yaitu sebagai wujud rasa bhakti atas karunia Tuhan Yang Maha Esa. Pelaksanaan etika atau susila keagamaan pada khususnya umat Hindu, dalam melaksanakan kehidupan keagamaan tidak hanya bertujuan untuk menghubungkan diri kehadapan Ida Sang Hyang Widhi Wasa, akan tetapi juga sebagai yadnya berfungsi untuk berinterakssi dengan sesama umat manusia. Interaksi sosial relegius terjadi pada pola etika keagamaan.
Penerapan etika umat Hindu bagi masyarakat Hindu di Desa Bagorejo dalam menjaga perbedaan dalam kebersamaan untuk menciptakan masyarakat yang damai dan sentosa dapat dilakasanakan dengan baik, dan penuh kesadaran akan perbedaan. Sebagaimana dalam Kitab Reg Veda 191.3 menyatakan bahwa: "Wahai umat manusia! Pikirkanlah bersama. Bermusyawarahlah bersama, satukan hati dan pikiranmu satu dengan yang lainnya. Aku anugrahkan pikiran dan ide yang sama dan fasilitas yang sama pula untuk kerukunan hidupmu.

Dengan demikian jelaslah bahwaaanya umat Hindu yang ada di Desa Bagorejo sangat menjunjung tinggi kebersamaan sebagai wujud dari penerapan ajaran etika dan susila yang baik guna menciptakan perdamaian dan kasih sayang yang tulus kepada semua umat manusia. Etika dan susila yang baik merupakan cerminan bagi umat beragama dalam mengamalkan ajaran agamanya masing-masing.

\section{Wujud Nilai dan Sikap Toleransi Diantara Individu.}

Agama dan kultur yang berkembang dimasyarakat tidak dapat dipisahkan, karena agama akan dipahami melalaui kultur yang berkembang dimasyarakat. Pemahaman kultur agama dan masyarakat di Indonesia, dapat dipahami melalaui pelaksanaan dan penerapan etika dan moralitas dari masingmasing. Penerapan etika dan susila untuk memberikan pemahaman agama dan budaya kepada seluruh masyarakat beragama. Sehingga mampu menumbuhkan sikap kebersamaan dalam keanekaragaman. Naim dan Sauqi (2008:77) pluralisme merupakan keberadaan atau toleransi keragaman etnik atau kelompok-kelompok kultural dalam suatu masyarakat atau Negara serta keragaman kepercayaan atau sikap dalam suatu badan, kelembagaan dan sebagainya. 
Pluralisme semacam ini disebut dengan pluralisme sosial. Untuk merealisasikan konsep tersebut perlu adanya toleransi.

Toleransi keberagamaan di Desa Bagorejo bagi umat Hindu dilaksanakan pada saat hari Raya Galungan yang diyakini memberikan berkah bagi yang melaksanakan, akan tetapi sikap toleransi tidak hanya diimplentasikan pada saat hari raya saja, sikap toleransi tetap selalu terjaga pada setiap hari. Kehidupan toleransi dirasakan sangat indah dan damai di Desa Bagorejo. Dengan demikian bahwa konsep pluralisme sosial ini perlu diterapkan seluruh lapisan masyarakat, penerapan etika dan susila yang dalam ajaran agama Hindu, tidaklah memandang pada intern umat Hindu, akan tetapi penerapan etika dan susila yang baik, perlu diterapkan kepada seluruh umat manusia agar terjalin hubungan yang harmonis.

\section{Wujud Ikatan Sosial Relegius diMasyarakat.}

Berdasarkan Kamus Besar Bahasa Indonesia,"social" yang artinya segala sesuatu mengenai masyarakat, kemasyarakatan, suka memperhatikan kepentingan umum. Sosial suatu hubungan antara individu dengan individu, kelompok dengan individu maupun kelompok dengan kelompok (Tim Penyusun, 2002:438). Religius atau religi berasal dari bahasa latin religio yang berarti Agama atau ajaran Agama. Religi menurut Kamus besar bahasa Indonesia adalah Kepercayaan kepada Tuhan, Kepercayaan akan adanya kekuatan adi kodrat di atas Manusia (Tim Penyusun, 2002:945). Menurut Abu Ahmadi religi atau Agama dalam pengertian "Addien" (bahasa arab) merupakan wahyu yang bersumber dari Tuhan. Karena iu Agama merupakan cara berfikir dan merasa dalam kehidupan suatu kesatuan sosial mengenai hubungan dengan Tuhan Yang Maha Esa.

Penerapan etika Hindu di Desa Bagorejo dapat diwujudkan dalam pelaksanaan ikatan sosial relegius masyarakat. Sehingga dalam pandangan ikatan sosial relegius masyarakat agama merupakan cara pandang atau cara berpikir masyarakat terhadap sistem keagamaan yang ada di lingkungan sosial. Fenomena ini diwujudkan dengan kebertahanan masyarakat terhadap ikatan sosial yang terjalin dengan utuh dan kokoh. Ikatan sosial relegius dalam masyarakat, menjadikan masyarakat selalu dalam keadaan yang damai dan harmonis.

Implementasi Yang Dilakukan Umat Hindu Di Desa Bagorejo Kecamatan Srono Dalam Mewujudkan Sikap KeBhinekaan Pada Saat Hari Raya Galungan.

1. Implementasi Multikulturalisme Dalam

\section{Perbedaan}

Keberagamaan yang terdapat di Desa Bagorejo sangat plural, baik dari segi agama yang dianut, suku, adat istiadat dan keyakinan yang berbeda-beda. Kehidupan masyarakat Bagorejo yang sebagian besar sebagai petani, dalam menjalankan kehidupan sehari-hari dengan hidup yang damai dan tidak adanya pemikiran membeda-bedakan individu-indivdu. Berdasarkan observasi yang dilakukan kehidupan masyarakat di Desa Bagorejo dalam aktivitas kehidupan sehari-hari di sawah dapat saling membantu dalam kehidupan bertani, dari segi menanam tanaman, membagi air disawah, dalam pekerjaaan lainnya, hampir tidak ada perbedaan diantar mereka meski dalam kehidupan beragama mereka berbeda-beda. Kehidupan masyarakat di Desa Bagorejo 
yang sangat multikultur adalah sebagai cerminan untuk melaksanakan kehidupan yang damai dalam segi kehidupan manusia. Praktek kehidupan multikultur nampak dengan adanya semangat gotong royong dalam kehidupan sosial masyarakat. Tidak andanya sikap individual dan ego sentris yang menitik beratkan pada satu golongan atau satu suku agama dan keyaikinan dalam kehidpan sehari hari.

Berdasarkan observasi yang dilakukan di Desa Bagorejo pada pelaksanaan hari raya Galungan banyaknya umat non Hindu yang ikut serta dalam pembuatan hiasan penjor yang digunakan umat Hindu sebagai simbol dalam pelaksanaan hari raya Galungan, dan pelaksanaan anjangsana tetap terlaksana dengan umat yang lainnya berkunjung kerumah umat Hindu. Kenyataan ini menandakan bahwa kehidupan yang multikulturalisme dapat terjaga dan dapat dilaksankan bahwa dipertahankan oleh masyarakat yang ada di Desa Bagorejo.

Multikultural dapat diartikan sebagai keragaman atau perbedaan terhadap suatu kebudayaan dengan kebudayaan yang lain. Sehingga masyarakat multikultural dapat diartikan sebagai sekelompok manusia yang tinggal dan hidup menetap di suatu tempat yang memiliki kebudayaan dan ciri khas tersendiri yang mampu membedakan antara satu masyarakat dengan masyarakat yang lain. Setiap masyarakat akan menghasilkan kebudayaannya masing-masing yang akan menjadi ciri khas bagi masyarakat tersebut.

\section{Wujud Persatuan Bangsa Sebagai Kerukunan Antar Umat Beragama}

Terwujudanya kerukunan antar umat beragama merupakan kehidupan yang sangat penting didalam suatu masyarakat yang majemuk. Keberadaan masyarakat di Indonesia yang menganut berbagai macam ajaran agama, keyakinan, budaya adat istiadat yang berbeda-beda, sangat mendambakan kehidupan yang rukun dan damai. Masyarakat yang ada di Desa Bagorejo sangat heterogen dan plularis. Berdasarkan observasi yang dilakukan bahwanya keberadaan masyarakat di Desa Bagorejo sangat ruukun dan damai, hidup berdampingan dan saling menghormati keyakinanan ajaran agama yang dianutnya. Berdasarkan Peraturan Bersama Menteri Agama Dan Menteri Dalam Negeri Nomor 9 Tahun 2006. BAB I Pasal 1 Dalam Peraturan Bersama ini yang dimaksud dengan: (1) Kerukunan beragama adalah keadaan hubungan sesama umat beragama yang dilandasi toleransi, saling pengertian, saling menghormati, menghargai kesetaraan dalam pengamalan ajaran agamanya dan bekerjasama dalam kehidupan bermasyarakat, berbangsa dan bernegara didalam Negara Kesatuan Republik Indonesia berdasarkan Pancasila dan Undang-Undang Dasar Negara Republik Indonesia Tahun 1945.

Solidaritas dan kerukunan umat beragama di Desa Bagorejo dapat dilaksanakan oleh umat Hindu dalam berbagai kegiatan kegamaan seeperti hari Raya Galungan dan lain sebagainya.Berdasarkan pendekatan teori perubahan budaya terhadap pelaksanaan hari raya Galungan di Desa Bagorejo Kecamatan Srono, bahwasanya hari raya Galungan bagi masyarakat Hindu di Desa Bagorejo, tidak hanya untuk melaksanakan ajaran agama saja, akan tetapi hari raya Galungan yang didalam rangkaian masyarakat terdapat pelaksanaan anjangsana sebagai wujud pemersatu masyarakat di Desa Bagorejo. Pelaksanaan anjangsana tidak sebatas silahturami kerumah tetangga, kerabat ataupun saudara. Pemaknaan yang mendalam telah mengalami pemaknaan dan perubahan yang signifikan terhadap konsep untuk mempererat dan mempersatuan masyarakat di Desa.

Perubahan pemaknaan pelaksaan hari raya Galungan yang secara kultur hanya dilaksanakan umat Hindu hanya sebatas bersembahyang saja dan anjangsana 
kesesama Hindu. Akan tetapi bagi masyarakat Hindu Jawa yang ada di Desa Bagorejo dalam konteks pelaksanaanya, pelaksanaan hari raya Galungan banyak mengalami perubahan dalam konteks kultur. Dengan adanya pemaknaan anjangsana yang dilaksanakan di Desa Bagorejo, menjadikan masyarakat lebih kondusif dalam berinteraksi dengan masyarakat lain.

\section{Perspektif Upacara Hari Raya Galungan Dipandang Dari Bhineka Tunggal Ika \\ 1. Menumbuhkan Sikap dan Psikologi Jiwa Keagamaan Pada Diri ManusiaDenganSaling

Menghormati Antar Umat
Beragama.

Pelaksanaan hari raya setiap agama membawa dampak yang positif bagi perkembangan psikologi umat manusia. Datangnya hari raya atau hari besar agama membawa kegembiraan bagi pemuluknya. Begitupula dengan masyarakat Hindu datangnya hari raya Galungan membawa kegembiraan bagi pemeluknya dari anakanak, remaja, dewasa dan yang usia lanjut pun ikut gembira dengan datangnya hari raya.

Perilaku keagamaan sangat berpengaruh terhadap jiwa keagamaan pada setiap individu utuk merayakan hari besar agamanya. Datangnya hari raya Galungan bagi umat Hindu, pada khususnya pelaksanaan hari raya Galungan di Desa Bagorejo, membawa perubahan sikap dan perilaku untuk meningkatkan getaran emosi keagamaan dalam menyambut datangnya Hari Raya Galungan.

Pada pengkajian Psikologi Agama ada dua kata yang memiliki makna masingmasing yaitu kata "Psikologi dan Agama". Kata Psikologi digunakan secara umum untuk ilmu tentang tingkah laku dan pengalaman manusia, dengan tujuan utamanya adalah mengungkapkan faktorfaktor yang berpengaruh pada perilaku (persepsi) manusia. Agama adalah kepercayaan kepada Tuhan serta segala sesuatau yang terkait dengan anjuran-Nya, sehingga dapat memberikan rasa aman dan memiliki ketetapan hati dalam menghadapi hidup. Jadi pengertian dari "Psikologi Agama" adalah cabang psikologi yang menyelidiki sebab-sebab dan ciri psikologis dan sikap-sikap yang religious atau perjalanan religious dan beragai fenomena dalam individu yang muncul dari atau menyertai sikap dan pengalaman tersebut.

\section{Kriteria Kematangan Beragama}

Manusia mengalami dua macam perkembangan, yaitu perkembangan jasmani dan perkembangan rohani. Perkembangan jasmani diukur berdasarkan umur kronologis. Puncak perkembangan jasmani yang dicapai manusia disebut kedewasaan. Sebaliknya tingkat kematangan rohani diukur berdasarkan tingkat kemampuan (abilitas). Pencapaian tingkat abilitas tertentu bagi perkembangan rohani disebut kematangan (masturity) (Jalaludin, 2010:123).

Sedangkan faktor lingkungan antara lain: 1) keluarga, 2) sekolah. Selain itu faktor lain yang ikut mempengaruhi kepribadian seseorang yaitu kebudayaan tempat seseorang dibesarkan. Kebudayaan yang menekankan pada norma yang didasarkan kepada nilai-nilai luhur seperti kejujuran, loyalitas, kerjasama, bagaimanapun akan memberi pengaruh dalam membentuk pola dan sikap yang merupakan unsur dalam kepribadian seseorang. Demikian pula halnya dengan kematangan beragama. Kemampuan seseorang untuk mengenali atau memahami nilai agama terletak pada nilai-nilai luhurnya serta menjadikan nilai-nilai dalam bersikap 
dan bertingkah laku merupakan ciri dari kematangan beragama (Jalaludin, 2010:125). Jadi kematangan beragama terlihat dari kemampuan seseorang untuk menghayati, serta mengaplikasikan nilainilai luhur agama yang dianutnya seharihari. Ia menganut suatu agama karena menurutnya agama tersebutlah yang terbaik. Karena itu ia berusaha menjadi penganut yang baik.

\section{Penerapan Dan Mengamalkan Ajaran Agama Hindu}

Masyarakat Hindu di Kecamatan Bagorejo Kabupaten Banyuwangi, dewasa ini dalam kehidupan dan aktivitas keagamaan tidak dapat dipisahkan dengan keberadaan penyuluh agama Hindu untuk memberikan pemahaman dan pemaknaan ajaran agama Hindu. Penyuluh agama Hindu berupaya memberikan pelayanan kepada umat Hindu di Kecamatan Bagorejo Kabupaten Banyuwangi. Eksistensi penyuluh agama Hindu, memegang peranan penting untuk menyampaikan dharma wacana kepada umat manusia.

\section{SIMPULAN}

Etika Hindu mampu menjaga kebersamaan antar umat beragama, guna menciptakan suasana yang damai dan harmonis dalam setiap perbedaan individu dan golongan. Etika dan susila Dlam ajaran agama Hindu sangat mengutamakan kebersamaan dan memandang semua mahluk adalah sama tidak bedanya. Penerapan etika dan susila dalam ajaran agama Hindu menerapkan sikap toleransi dalam berbagama. Ikatan sosial relegius dikalangan masyarakat dapat diterapkan dengan baik oleh maysarakat Hindu untuk menjaga sikap toleransi dalam keberagamaan

\section{DAFTAR PUSTAKA}

Ali, Sayuti. 2003. Metodologi Penelitian Agama (Pendekatan Teori dan Praktek). PT. Raja Grafindo Persada.

Arikunto, Suharsimi. (2002). Prosedur Penelitian Suata Pendekatan Praktek. Jakarta: PT Rineka Cipta.

H. Jalauddin. 2005. Psikologi Agama Memahami Perilaku Keagamaan dengan Mengaplikasikan.

Iqbal, Hasan. 2002. Pokok - Pokok Metodelogi Penelitian Dan Aplikasi. Indonesia: Ghalia.

Jalaludin, H. 2010. Psikologi Agama. Jakarta, Raja Grafindo Persada.

Naim, Ngainun dan Ahmad Sauqi. 2008. Pendidikan Multikultural Konsep Dan Aplikasi. Jogyakarta: AR-Ruz Media Group.

Riduwan. 2004. Metode Dan Tekhnik Penyusunan Tesis. Bandung: Alfa Beta. Cetakan Pertama.

Sugiyono. 2007. Metode Penelitian Pendidikan ( Pendekatan Kuantitatif, Kualitatif dan R\&D). Bandung: Alfabeta

Sugiyono. 2010. Metode Penelitian

Pendidikan ( Pendekatan Kuantitatif,

Kualitatif dan $R \& D)$ ). Bandung:

Alfabeta.

Tim Penyusun. 2002. Kamus Istilah Agama Hindu. Denpasar: Pemda Tk. I Bali.

Tim Penyusun. $2005 . \quad$ HasilhasilPesamuhanAgungParisadaHindu Dharma Indonesia. Bandar Lampung. Parisada Hindu Dharma Pusat.

Tim Penyusun. 2007. Pedoman Kerukunan Umat Beraga Hindu. Jakarta: Mitra Abadi Press.

Zuriah, Nurul. 2007. Metode Penelitian Sosial Dan Pendidikan (TeoriAplikasi). Jakarta: PT Bumi Aksara. 